\title{
Perceived Factors Influencing Career Choice of the Undergraduate Students of Public Universities in Bangladesh
}

\author{
Sayed Azharul Islam ${ }^{1}$, Gazi Minhazur Rahman' ${ }^{1}$ and Md. Mahdi Al Muhtasim Nibir ${ }^{2}$ \\ ${ }^{1}$ Human Resource Management Discipline, Khulna University, Bangladesh; and ${ }^{2}$ Mass Communication \& Journalism \\ Discipline, Khulna University, Bangladesh. \\ *Correspondence: azharulsayed@gmail.com (Sayed Azharul Islam, Assistant Professor, Human Resource Management \\ Discipline, Khulna University, Bangladesh).
}

\begin{abstract}
People around the globe, especially the educated ones, have become very much concerned about their careers. University students in Bangladesh are generally treated as one of the most serious segments having the intention for selecting career paths. In this regard, several factors are having different levels of influence over the career choice decision. This study aims at identifying and ranking the factors influencing the career choice of undergraduate students of public universities in Bangladesh. The study is quantitative where the perception of 384 undergraduate students of public universities of Bangladesh has been measured to find the level of influence of multiple factors influencing their career choice. A convenience sampling technique was used to choose the respondents. This study finds several factors having a different degree of impact on the choice of career. Sixteen factors have been identified through an extensive literature review based on which students' perception was measured using a five-point Likert scale. Out of these 16 factors, 5 factors have been found strongly influential, 6 factors have been marked as moderately influential, and the rest 5 factors have been ranked as a low influential factor as perceived by the respondents. However, no established scale was utilized to rank the factors rather it has been performed based on mean value developing a scale using the rule of thumb. After a careful analysis, the personality of the students has been identified as the most influential factor for the career choice with a mean of 4.28 and standard deviation of .962 whereas the influence of relative has been marked as the least influential factor with a mean of 2.67 and stand ard deviation of 1.426 .
\end{abstract}

Keywords: Career choice, Management, Influencing factors, Public University and Undergraduate students.

\section{INTRODUCTION:}

Career - Career refers to the part of life-related someone's employment and usually, it is the total of different jobs one holds during lifetime (Phifer, 2003). According to Collins Dictionary, (2018), a career means the jobs or occupations in which a person spends a long time. In another way, it is the chosen profession or occupation through which someone passes his economic life. It is the path or way of someone's life (Collins Dictionary, 2018). A career helps a person to lead a life that he/she expects. However, only a successful career can meet one's expectations and this success of career depends UniversePG I www.universepg.com on how well one can decide his/her career. This decision process is known as career decision (Lore, 2012). Career planning, according to Rogers et al. (2008), is a decision-making process in which personal characteristics and contextual factors play a significant influence. Individual objectives, personal traits, and social interaction all have an impact on the decision-making process in this setting. A career is simply a way of life or a long-term project of one's life that may be in business, service, agriculture, farming, teaching, Medicare, engineering, law, research, and so forth. However, one may or may not make money through his/her career (Care, 1984). 
Career Planning - Career planning is a continual process of discovery in which a person gradually creates his or her professional idea as a consequence of his or her own value system's skills, talents, requirements, motivations, and ambitions. Career based planning is very methodical and complete process of focusing on career growth and putting plans in place, as well as self-assessment and opportunity analysis, and evaluating the outcomes (Manolescu, 2003). Everyone gets some alternative career paths out of which one path is selected as one's career and this selection process is known as a career choice. Career choice bases on some internal and external factors like gender, age, socio-economic status, birth order, religion, habitation, age, race, traits, personality, perceptions, mentor's influence, parental influence, social condition, education background, hobby, personal interest, physical structure, and so on as noted by different authors including Palmer, (1981); Ghuangpeng, (2011); Omari, (2014); Micallef and Gatt, (2018).

Importance of Career Planning - Successful careers are managed through a pragmatic and careful career planning. Selecting the right professional path is becoming increasingly important for young people in the twenty-first century since they must consider a variety of factors such as gender, age, parental guidance and peer pressure while making a decision. Career growth is a constant process of attracting the labor world, all the way to employment opportunities presented to them (Ferry, 2006). The worldwide changes of twenty-first century and the circumstances of the present age have created an environment in which virtually everything competes with one another. Students have to adapt with the fast changes of the contemporary world and this kind of adjustment necessitates a certain level of dedication, drive, and forethought. Within this context, career planning is very important at the very beginning of the educational journey. Choosing an unachievable career can result in aggravation. Scholars suggest that proper care and attention should be given while formulating career planning since career choice is correlated with job satisfaction. A lifetime negative consequence may occur if the career choice is worn (Zaidi and Iqbal, 2012).

Career Planning Process - Career planning has become one of the crucial activities, especially for the present generation because of the rapid transformation in society, economy, and technology. Career UniversePG I www.universepg.com planning is the progression of designing and implementing a career. As all individuals have different personalities and preferences, it is tough to establish an exact step-by-step sequence for a career planning process. Lock, (2004) proposes the following career planning process evolving from various sources.

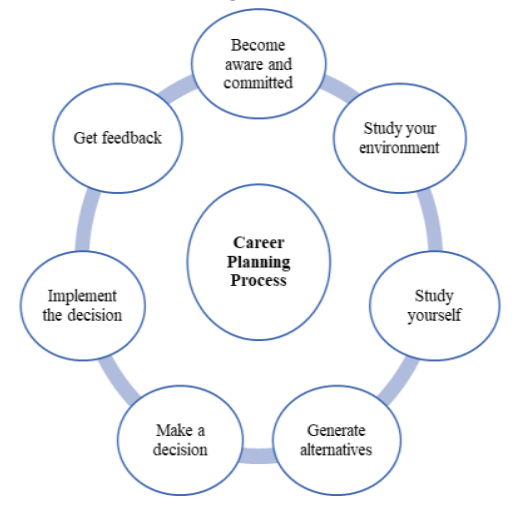

Fig 1: Career Planning Process (Source: Based on Lock; 2004).

Career Planning in Bangladesh - By considering the importance of career planning and development education, the Bangladesh government has initiated career education courses from secondary to tertiary education in the country (NCTB, 2018). Career education has a long history though it is a relatively new branch of knowledge in Bangladesh. However, for long, career-related education in Bangladesh has been initiated for ensuring the quality of graduates as well as to make them prepared for the globally competitive job market (NCTB, 2018; Milon et al., 2021).

\section{Literature Review}

In the extent of career choice, a good number of studies have been conducted across the world. The studies were conducted from different perspectives. The following sections introduce the features which were found responsible for influencing the career choice of diverse types of people of different regions and classes.

Family - A good number of researches around the world show a significant relationship between family factors and career choice. (Guerra and Braungart Rieker, 1999) discovered that the expectations of parents and their direct support and care play a significant role in the career decisions of their children. Kniveton, (2004) states that family influences career choice directly or indirectly by providing guidance and related information. In a research on the undergraduate students of public universities of Kenya, five family factors namely parent's advice, parent's career, sibling's advice, sibling's career, and 
uncle/auntie's advice were taken into attention. Out of these factors, parent's advice has been found most influential having a mean value of 2.4 (not so high). However, other factors have shown lower influence on individuals (Maina, 2013). Schroder et al. (2011) have said in their study that family business background has an influence on adolescents' career choice but that influenced is mediated by some personality traits, gender, perceived parental job rewards, their identification with the family business, parental succession preference, and so on. Ayiah et al. (2014) specify students are highly influenced by their father, mother, siblings' career, and advice while selecting their career. Clutter, (2010) shows that parental influence plays a significant role in deciding children's careers. A South Africa-based study depicts that family plays the most significant role in choosing a career besides some other factors like self-ability and teachers' influence (Shumba and Naong, 2012).

Gender - Several researchers have found out that gender plays an influential role in choosing the career of students. A study on undergraduate engineering students finds that females are more likely to be influenced by others than males (Mishkin et al., 2016). In a study by Maina, (2013), only 57 (20.1\%) respondents out of 284 stated that there is some male-dominated career. Male-dominated career includes STEM (Science, Technology, Engineering, and Math) and some other careers where there is a requirement of moderately to the high level of physical involvement. Kushwaha and Hasan, (2005) find that male students are more likely to choose appropriate careers due to their perception of being family income earners. A research finding of Javed and Tariq, (2016) states that males face fewer difficulties than females in career decision-making. Akhund et al. (2012) alleged that gender influence has been found while choosing a specialized career by medical graduates. Thus, Kenya based study finds no major variance in career choosing factors by gender (Edwards and Quinter, 2011).

Mentor's/Teacher's Advice - The teacher's advice was supposed to influence students' career choices. Ayiah et al. (2014) have stated that teacher's careers as well as advice influence the career of their students. Morales et al. (2016) emphasize that teacherstudent interaction, teaching techniques; materials influence the students in choosing a career in science and mathematics teaching. Career counseling throUniversePG I www.universepg.com ugh expert/mentor is essential for helping the students to choose the best fit career (Ryan, 2018). Shumba and Naong, (2012) stated that teacher's advice plays a significant role in deciding students' careers and aspirations.

Mentorship by Friends - Peer has influence on anyone's way of life, social activities, academics, appearance and generally the socialization process (Sebald, 1992). Maina, (2013) conducted a study on the undergraduate students of public universities of Kenya and found that that $31 \%$ students feel that they are influenced by the mentorship of their friends while choosing a career. Peer influence can help youngsters establish professional options and make better decisions (Naz et al., 2014).

Other Socio-demographic Factor - A research on the relationship between career choice and sociodemographic profile of science students of University of Pune, India depicts that majority of the students (73\%) opting for science education are from urban areas and the rest 27 percent of the students were from rural areas. Other demographic factors including medium of instruction and gender do not have any significant relationship with students' choosing science-related career (Shaikh, 2013).

Individual Values - A study on the students of a Turkish University finds that individual values which include silence, individualism, achievement, universalism, positivism have an impact on choosing a career. One of the findings is that individualism, achievement, and universalism are more likely to lead someone towards entrepreneurship (Kaygin and Gulluce, 2013).

Prior Knowledge - This empirical study depicts that an individual's prior knowledge influences career decision making and this prior knowledge comes through mentorship, socialization, training, research and consultation, industrial attachment, etc (Nyamwange, 2016). Ozbilgin et al. (2004) in a cross-cultural study on MBA students of Britain, Israel, and Turkey reveal that individuals use their human capital and personal capacity to make a career decision.

Personality - Personality is a vital trait in choosing a career and making a career decision. A relationship has been found between Holland's personality types and career choice (Aljojo, 2016). Three factors namely personality, environment and opportunities were studied to measure the level of influence on career 
choice of the seniors of Germantown High School, USA where personality was found as the most significant factor influencing career choice decision (Borchert, 2002). Holland's theory about personality and vocational choices postulates that people are most satisfied when occupational choices match their personalities. According to Holland's theory, there is a correlation between personality and the most appropriate work environment which will result in individuals experiencing successful career development, and happier and stress-free lives (Greenberg \& Baron, 2008). The theory is based on six different personality types, and each is associated with a specific work environment in which the individual is most likely to thrive.

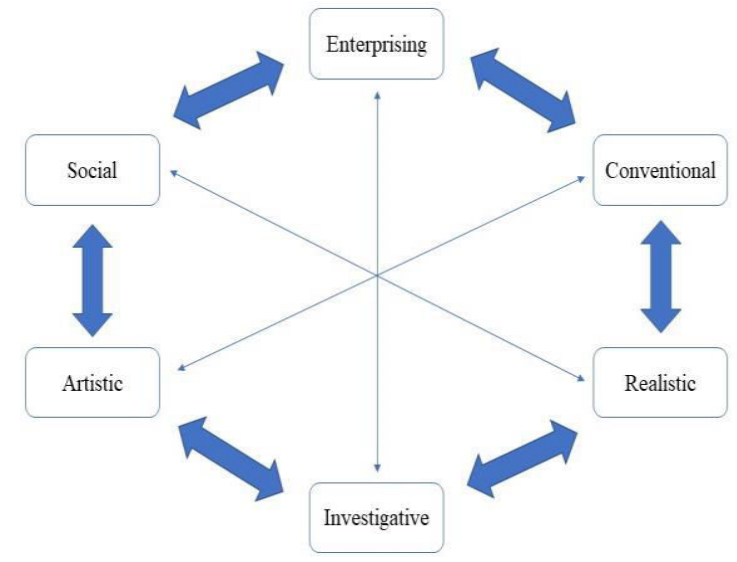

Fig 2: Holland's Theory (Source: Based on Greenberg \& Baron; 2008).

Passion and Personal Interest - Passion is a strong feeling about something and a strong belief in something. Personal interest is the desire to devote time and attention to something or to be interested in something and to discover more about something. Sibson, (2011) finds that passions like sports, event management, and recreation management have an impact on career choice. Afaq et al. (2017) have done a study on $120 \mathrm{MBA}$ and BBA students of Karachi, Pakistan. It shows that 'personal interest in the subject' is the most dominant factor in career choosing.

Social System and Culture - Individuals' perceptions towards particular careers may depend on their cultural values. Collectivistic people may perceive voluntary work as meaningful because it benefits the interests of their community (Ismail \& Lu, 2014). They also prefer to choose a career that provides them with training opportunities and working conditions than freedom or challenge of work. On the other hand, individualistic people are self-centered and desire to achieve their own goals, and they prioritize independence and challenge as more important than training opportunities or working conditions (Carrero, 2002). Baines, (2009) in his study describes that the factors which influence career choice differ from culture to culture. The career choice decision of western culture (individualism) is less likely to be influenced by others than that of eastern culture (collectivism).

Growth Opportunities - Abbasi and Sarwat's, (2014) study on Pakistani graduates shows that they give significant focus on growth opportunities while deciding a career. This is confirmed by the study of Myburgh, (2005) which found that promotion and career advancement are two of the most influential career choice factors for first-year accounting students.

Prestige of Profession - Prestige as an inherent quality; It is sensed that certain jobs are more worthwhile than others, without being able to pinpoint exactly why. Eremie, (2014) has done a study on Nigerian students. This study based in Nigeria shows that both male and female students consider the relative prestige of the profession while choosing their careers.

\section{Research Objectives}

The study's major goal was to look at the factors that influence undergraduate students' career choices in Bangladesh's public universities. The following particular objectives were used to attain the main goal -

a) To determine the factors that influence a person's career choice

b) To determine the importance of various factors in determining career choice.

c) To rank the factors according to their level of influence.

\section{METHODOLOGY:}

The study is descriptive and quantitative. A structured questionnaire was prepared using variables derived through extensive literature. The respondents were requested to express their perceptions on a fivepoint Likert scale ranging from 1 to 5 (1- strongly disagree to 5- strongly agree). The total estimated population of this study is 2595299 as described in the UGC report. Using a sample size table considering a $95 \%$ level of confidence with a 5\% margin of error, the sample size is $\mathrm{N}=384$ (Singh and Masuku, 2014). The respondents were selected using the convenience sampling technique as it was found 
suitable in this situation where the respondents are very much scattered. Link of online questionnaires was sent to 450 respondents. Among the 395 responded, 384 were found suitable for use. Data have been analyzed using SPSS Version 24 though no sophisticated tool has been used. To rank the factors, researchers have developed a scale using the rule of thumb. Ranking of the career choice factors has been done using mean value only.

\section{ANALYSIS AND FINDINGS:}

Table 1: Demographic Analysis (Source: Field Survey).

\begin{tabular}{|c|c|c|c|}
\hline & Particulars & Frequency & Percent \\
\hline \multirow{3}{*}{ 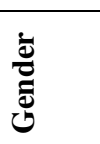 } & Male & 239 & 62.2 \\
\hline & Female & 145 & 37.8 \\
\hline & Total & 384 & 100.0 \\
\hline \multirow{4}{*}{ 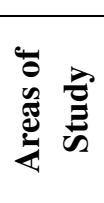 } & Arts, Social Science and Humanities & 73 & 19.0 \\
\hline & Business Studies & 135 & 35.2 \\
\hline & Medical & 30 & 7.8 \\
\hline & Science, Engineering, and Technology & 146 & 38.0 \\
\hline & Total & 384 & 100.0 \\
\hline \multirow{6}{*}{$\begin{array}{l}\vec{D} \\
\frac{\vec{E}}{\omega} \\
\frac{0}{0} \\
\frac{0}{0} \\
\stackrel{0}{0}\end{array}$} & Bachelor 1st Year & 51 & 13.3 \\
\hline & Bachelor 2nd Year & 72 & 18.8 \\
\hline & Bachelor 3rd Year & 79 & 20.6 \\
\hline & Bachelor 4th Year & 140 & 36.5 \\
\hline & Bachelor 5th Year & 42 & 10.9 \\
\hline & Total & 384 & 100.0 \\
\hline
\end{tabular}

Bachelor $5^{\text {th }}$ year students are from Medical, Architecture, Pharmacy, and some other disciplines of study. Out of 384 respondents, 239 are males, and the rests 145 are females. Respondents belong to diversified educational backgrounds. Respondents from arts, social science, and humanities have been categorized in the same group where the total number is 73 . Out of the total respondents, 135 were from business studies background and 146 respondents are from Science, Engineering and Technology related fields and lastly, there were 30 respondents from the medical background who are students of different medical colleges. This table also shows the education level of the respondents where the maximum respondents are $4^{\text {th }}$-year undergraduate students (Table 1). From the above analysis, it is vibrant that the student's personality plays the most significant role in choosing the career for themselves as the mean of the respondents' response regarding the influence of their personality in choosing their career is 4.28 with a standard deviation of .962 which means that the dispersion of respondents' answer was .962 above or below the mean. The second strongest factor is financial benefits as generally expected. Influence from relatives in career choice has been identified as the least significant factor with a mean value of 2.67. Based on the above analysis, the following ranking of the factors can be made based on respective mean values (Table 2). As per the perception of the respondents, their Personality, Financial Benefits in a certain career, Passion of incumbents, Flexibility in jobs, Prestige of Profession are the most considerable factors in career choice. However, the mean values of the strongly influential factors are very much closed to each other ranging from 4.13 to 4.28 (Table 3).

Table 2: Factors Influencing Career Choice (Source: Field Survey).

\begin{tabular}{|l|l|l|l|}
\hline Questions & N & Mean & SD \\
\hline Q1: My family members (parents, siblings, and others) influence my career choice & 384 & 3.60 & 1.250 \\
\hline Q2: My relatives (uncle, aunts, cousin, and others) influence my career choice & 384 & 2.67 & 1.426 \\
\hline Q3: My teachers influence my career planning & 384 & 3.09 & 1.379 \\
\hline Q4: I am influenced by my friends in my career planning & 384 & 2.94 & 1.383 \\
\hline Q5: Seniors of my university influence my career planning & 384 & 3.07 & 1.381 \\
\hline Q6: Established people in the society directly or indirectly influence my career planning & 384 & 3.65 & 1.261 \\
\hline Q7: My neighbors and social groups have influenced my career planning & 384 & 2.80 & 1.427 \\
\hline
\end{tabular}




\begin{tabular}{|c|c|c|c|}
\hline Q8: My religion influences my career planning (restricts or allows certain careers) & 384 & 2.96 & 1.544 \\
\hline Q9: I feel my gender (male/female) type influences my career choice & 384 & 2.88 & 1.564 \\
\hline Q10: I feel that my personality drives me to certain career & 384 & 4.28 & .962 \\
\hline Q11: My passion/interest/hobby influences my career choice & 384 & 4.20 & 1.067 \\
\hline Q12: Prestige of profession is an important parameter to me in my career planning process & 384 & 4.13 & 1.112 \\
\hline Q13: I think the security of a job is a factor in influencing my career & 384 & 3.93 & 1.263 \\
\hline Q14: I feel that I consider the need for power as a factor behind choosing my career goal & 384 & 3.55 & 1.314 \\
\hline Q15: I consider flexibility in deciding my career goal & 384 & 4.13 & .993 \\
\hline Q16: I consider financial benefit in choosing my career goal & 384 & 4.22 & 1.017 \\
\hline
\end{tabular}

Table 3: Factors having a strong influence on career choice with the mean value ranging from 4.00 to 5.00 .

\begin{tabular}{|c|c|c|c|}
\hline Ranking & Factors & N & Mean Value \\
\hline 1 & Personality & 384 & 4.28 \\
\hline 2 & Financial Benefits & 384 & 4.22 \\
\hline 3 & Passion/interest/hobby & 384 & 4.20 \\
\hline 4 & Flexibility & 384 & 4.13 \\
\hline 5 & Prestige of Profession & 384 & 4.13 \\
\hline
\end{tabular}

Source: Field Survey

Table 4: Factors having a moderate influence on career choice with the mean value ranging from 3.00 to 3.99.

\begin{tabular}{|c|c|c|c|}
\hline Ranking & Factors & $\mathbf{N}$ & Mean Value \\
\hline 1 & Security of Job & 384 & 3.93 \\
\hline 2 & Established People & 384 & 3.65 \\
\hline 3 & Family Members & 384 & 3.60 \\
\hline 4 & Need for Power & 384 & 3.55 \\
\hline 5 & Teachers & 384 & 3.09 \\
\hline 6 & Seniors & 384 & 3.07 \\
\hline
\end{tabular}

Source: Field Survey

Table 5: Factors having a low influence on career choice with the mean value ranging from 2.00 to 2.99 .

\begin{tabular}{|c|c|c|c|}
\hline Ranking & Factors & N & Mean Value \\
\hline 1 & Religion & 384 & 2.96 \\
\hline 2 & Friends & 384 & 2.94 \\
\hline 3 & Gender & 384 & 2.88 \\
\hline 4 & Neighbors and Social Groups & 384 & 2.80 \\
\hline 5 & Relatives & 384 & 2.67 \\
\hline
\end{tabular}

\section{Source: Field Survey}

Among the 16 factors derived from previous literature above mentioned six factors namely- Security of Job, Established People, Family Members, Need for Power, Teachers, Seniors have a moderate influence on career choice decisions as perceived by the undergraduate students of public universities of Bangladesh (Rashid and Islam, 2020). It should be noted that though the security of a job has been categorized here as a moderate influential factor, the mean value of perceived influence is very much closed to those of strongly influential factors (Table 4). The above five factors namely- Religion, Friends, Gender, Neighbors, and Social Groups, Relatives have been perceived to have a low influence on career choice where the influence of relatives is the least influential factor among all. Point to be noted that among the respondents, 145 were female $(37.8 \%$ of total respondents), and still, the perceived influence of gender factor is only 2.88 which indicates Bangladeshi female students now feel fewer challenges in any kind of career than previous times (Table 5).

\section{CONCLUSION:}

The investigation into the perception of the undergraduate students depicts that their personality has a very strong influence on their career choice decision. So, parents, teachers, policymakers must give attention to these factors while guiding them towards a certain career path. They have marked financial benefits in a career as another most influential factor. That is why, to attract quality graduates in a certain profession, competitive compensation packages have to be offered. Along with these two fac- 
tors, the passion of incumbents, flexibility in jobs, and prestige of profession have been perceived to have a strong influence. The human resource managers can consider these factors carefully to attract quality graduates. As perceived by the respondents, six factors namely- security of a job, established people, family members, need for power, teachers, and seniors have a moderate influence on career choice decisions. Finally, factors namely- Religion, Friends, Gender, Neighbors and Social Groups, Relatives have been perceived to have a low influence on career choice. Career Planning and Development has already been included in the syllabus of secondary level education by NCTB. The findings of this research can be included in that book so that teachers and learners can understand the factors that drive the students' career choices from the perspective of our country.

\section{ACKNOWLEDGEMENT:}

At first, all gratefulness goes to the Almighty for keeping us healthy to complete this research paper. Gratitude goes to all the respondents who gave their valuable time for the survey and all others who directly or indirectly contributed in preparing this study.

\section{CONFLICTS OF INTEREST:}

The authors declared that there is no potential conflict of interest to publish this research paper.

\section{REFERENCES:}

1) Abbasi, M. and Sarwat, N. (2014). Factors Inducing Career Choice: Comparative Study of Five Leading Professions in Pakistan. Pakistan Journal of Commerce and Social Sciences, 8(3), pp.830-845. http://hdl.handle.net/10419/188172

2) Afaq Ahmed, K., Sharif, N. and Ahmad, N. (2017). Factors Influencing Students' Career Choices: Empirical Evidence from Business Students. J. of South. Asian Res. 2017, pp.115. https://doi.org/10.5171/2017.718849

3) Akhund, S., Shaikh, Z. and Kolachi, H. (2012). Career Related Choices of Medical Students from an International Medical College of Karachi, Pakistan. JLUMHS, 11(3), pp.180-184.

https://www.lumhs.edu.pk/jlumhs/Vol11No03/p dfs/v11n3oa01.pdf

4) Aljojo, N. (2016). Choosing a Career Based Personality Matching: A Case Study of King UniversePG I www.universepg.com
Abdulaziz University. International Journal of Advanced Computer Science and Applications, 7(2), pp.215-221. https://doi.org/10.14569/ijacsa.2016.070229

5) Ayiah-Mensah, F., Mettle, D. and Ayimah, J. (2014). Modeling the factors that influence career choice of technical and vocational students (A case study of Takoradi and $\mathrm{HO}$ Polytechnics). International $J$. of Mathematics and Statistics Studies, 2(5), pp.62-80. https://www.researchgate.net/publication/30177 $\underline{5805}$

6) Baines, J. (2009). What Are the Factors That Shape the Career Decisions of LSE Students? MA. University of Reading. http://eprints.1se.ac.uk/id/eprint/28750

7) Bangladesh University Grant Commission (2018). Annual Report 2017. Dhaka: Bangladesh University Grant Commission, p.30. http://www.ugc.gov.bd/site/annual_reports/ed1e d68d-c017-4e3e-a66c-ba1fb83fc0bc/Annual-

Report-2018

8) Borchert, M. (2002). Career Choice Factors of High School Students. MS. University of Wisconsin-Stout.

https://minds.wisconsin.edu/bitstream/handle/1 793/40311/2002borchertm.pdf? sequence $=1$

9) Braza, M. and Guillo, 1. (2015). SocioDemographic Characteristics and Career Choice of Private Secondary School Students. Asia Pacific J. of Multidisciplinary Research, 3(4), pp.78-84.

http://www.apjmr.com/wp-content/uploads/20 15/11/APJMR-2015-3.4.4.12.pdf

10) Care, N. (1984). Career Choice. Chicago Journals, 94(2), pp.283-320.

11) Carrero, M.R. (2002). The influence of individualism-collectivism on the career development of ethnic minorities in the United States. Unpublished PhD's thesis, The City University of New York, United States.:

12) Clutter, C. (2010). The Effects of Parental Influence on Their Children's Career Choices. MS. Kansas State University.

13) Collins Dictionary. (2018). Career definition and meaning | Collins English Dictionary. https://www.collinsdictionary.com/dictionary/e nglish/career

14) Edwards, K. and Quinter, M. (2011). Factors Influencing Students Career Choices among Secondary School students in Kisumu Muni- 
cipality, Kenya. J. of Emerg. Trends in Educat. Res. and Policy Stud., 2(2), pp.81-87. https://journals.co.za/doi/abs/10.10520/EJC135 $\underline{714}$

15) Eremie, M. (2014). Comparative analysis of factors influencing career choices among senior secondary school students in Rivers State, Nigeria. Arabian J. of Business and Management Review, 4(4), pp.20-25. https://platform.almanhal.com/Files/2/75594

16) Faitar, G. and Faitar, S. (2013). Teachers' Influence on Students' Science Career Choices. Amer. Intern. J. of Soc. Sci. 2(5), 10-16. https://citeseerx.ist.psu.edu/viewdoc/download? doi=10.1.1.1046.7575\&rep=rep1\&type $=$ pdf

17) Ferry, N, M. (2006). Factors Influencing Career Choices of Adolescents and Young Adults in Rural Pennsylvania. Journal of extension, 44(3), 73-95.

https://archives.joe.org/joe/2006june/rb7.php

18) Ghuangpeng, S. (2011). Factors Influencing Career Decision-Making: A Comparative Study of Thai and Australian Tourism and Hospitality Students. PhD. Victoria University, Melbourne.

19) Greenberg, J., \& Baron, R. A. (2008). Behaviour in organisations ( $9^{\text {th }} \mathrm{ed}$.). New Jersey: Pearson Education, Inc.

20) Guerra, A.L. \& Braungart-Rieker, J.M. (1999). Predicting career indecision in college students: The roles of identity form-ation and parental relationship factors. Career Development Quarterly, 47, 255-266. https://doi.org/10.1002/j.2161-0045.1999.tb0 0735.x

21) Ismail, M. \& Lu, H.S. (2014). Cultural values and career goals of the millennial generation: An integrated conceptual framework. The $J$. of Intern. Manag. Studies, 9(1), pp. 38-49. https://citeseerx.ist.psu.edu/viewdoc/download? doi=10.1.1.688.2150\&rep=rep1\&type $=$ pdf

22) Javed, Z. and Tariq, O. (2016). Career-decisions, Self-efficacy and Self-esteem among Students of Private and Government Academic Institutions. Pakistan Journal of Social and Clinical Psychology, 14(2), pp.42-46. https://gcu.edu.pk/wp-content/uploads/2020/ 04/pjscp20162-6.pdf

23) Kaygin, E. and Gulluce, A. (2013). The Relationship between Career Choice and Individual Values: A Case Study of a Turkish
University. International Journal of Humanities and Social Science, 3(3), pp.119-134. http://www.ijhssnet.com/journals/Vol 3 No 3 February 2013/11.pdf

24) Kniveton, B.H. (2004). The influences and motivations on which students base their choice of career. Research in Education, 72, 47-59. https://doi.org/10.7227/rie.72.4

25) Kushwaha, A. and Hasan, B. (2005). Career Decision Making as a Function of Personality Dimension and Gender. Journal of the Indian Academy of Applied Psychology, 31(1-2), pp.77-82.

http://medind.nic.in/jak/t05/i1/jakt05i1p77.pdf

26) Lock, R. (2004). Taking Charge of Your Career Direction: Career Planning Guide, Book 1. $5^{\text {th }}$ ed. Boston: Cengage Learning, pp.5-35. https://eric.ed.gov/?id=ED389917

27) Lore, N. (2012). The Pathfinder: How to Choose or Change Your Career for a Lifetime of Satisfaction and Success. $2^{\text {nd }}$ ed. New York: Simon and Schuster, pp.20-50.

https://www.goodreads.com/en/book/show/549 008.The Pathfinder

28) Maina, B. N. (2013). Factors Influencing Career Choices among Undergraduate Students in Public Universities in Kenya - A Case of Compassion International Sponsored Students. MA. University of Nairobi. http://erepository.uonbi.ac.ke/handle/11295/562 37

29) Manolescu, A. (2003) Human Resource Management, $4^{\text {th }}$ Edition, The Economic Publishing House, Bucarest, p.332.

30) Micallef, C. and Gatt, S. (2018). Gender Preferences and Science Career Choice. 3rd International Conference on Hands-on Science, pp.648-657.

https://www.um.edu.mt/library/oar/handle/1234 $\underline{56789 / 19179}$

31) Milon M, Islam MR, and Khan MAR. (2021). Employability skills of business graduates in job markets of Bangladesh: investigating weaknesses and suggesting improvements, Int. J. Manag. Account. 3(1), 20-27. https://doi.org/10.34104/ijma.021.020027

32) Mishkin, H., Wangrowicz, N., Dori, D. and Dori, Y. (2016). Career Choice of Undergraduate Engineering Students. Procedia Social and Behavioral Sci., 228, pp.222-228. https://doi.org/10.1016/j.sbspro.2016.07.033 
33) Morales, M., Avilla, R. and Espinosa, A. (2016). Does gender inequality influence interest in pursuing a career in science or mathematics teaching? Issues in Educational Research, 26(1), pp.65-81.

https://search.informit.org/doi/abs/10.3316/ielap a.020718308264715

34) Myburgh, J. E. (2005). An empirical analysis of career choice factors that influence firstyear Accounting students at the University of Pretoria: A cross-racial study. Meditari Accountancy Research, 13(2), 35-48.

https://journals.co.za/doi/abs/10.10520/EJC725 $\underline{03}$

35) Naz, A., Saeed, G., and Khan, N. (2014). Peer and Friends and Career Decision Making: A Critical Analysis. Middle-East J. of Scientific Research, 22(8), (1193-1197), p.1193. https://www.idosi.org/mejsr/mejsr22(8)14/13.p $\underline{\text { df }}$

36) NCTB, (2018). Curriculum for secondary level. Available at:

http://www.nctb.gov.bd/site/files/cfea465e02d9-4aef-ae75-1ea7ca891753/Secondary

37) Nyamwange, J. (2016). Influence of Student's Interest on Career Choice among First Year University Students in Public and Private Universities in Kisii County, Kenya. J. of Education and Practice, 7(4), pp.96-102. https://eric.ed.gov/?id=EJ1092415

38) Omari, S.G. (2014). Strategic Factors That Influence Students' Career Choice in Kenyan Universities: A Study of United States International University, MBA.

http://erepo.usiu.ac.ke/handle/11732/91

39) Ozbilgin, M., Kusku, F. and Erdogmus, N. (2004). Explaining Influences on Career 'Choice' in Comparative Perspective. Digital Commons@ILR.

https://www.tandfonline.com/doi/abs/10.1080/0 9585190500314797

40) Palmer, S. (1981). The relationship between birth order and teaching as a career. MA. The University of British Columbia.

https://open.library.ubc.ca/collections/831/831/it ems/1.0054319

41) Phifer, P. (2003) College Majors and Careers, $5^{\text {th }}$ Edition. New York, Ferguson Publication. https://www.betterworldbooks.com/product/det ail/college-majors-and-careers-5th-edition-089 $\underline{4343785}$
42) Rashid MH and Islam MA. (2020). Impacts of unemployment on graduates in Bangladesh: a case study, Br. J. Arts Humanit., 2(5), 87-94. https://doi.org/10.34104/bjah.020087094

43) Rogers, M.E., Creed, P.A., \& Glendon, A.I. (2008). The role of personality in adolescent career planning and exploration: A social cognitive perspective. Journal of Vocational Behavior, 73, 132-142. https://doi.org/10.1016/j.jvb.2008.02.002

44) Ryan, C. (2018). Factors Influencing Adolescent Career Choice with Particular Emphasis on the Role of Personality. International Conference- The future of education, Trinity College Dublin (Ireland). https://bit.ly/371u6MB

45) Schroder, E., Schmitt-Rodermund, E. and Arnaud, N. (2011). Career Choice Intentions of Adolescents with a Family Business Background. Family Business Review, 24(4), pp.305-321. https://doi.org/10.1177/0894486511416977

46) Scribbr, (2020). Descriptive Research Design | Definition, Methods and Examples. [Online] Available at:

https://www.scribbr.com/methodology/descripti ve-research

47) Sebald, H. (1992). Adolescence: A Social Psychological Analysis. Englewood Cliffs, NJ: Prentice Hall.

https://www.worldcat.org/title/adolescence-asocial-psychological-analysis/oclc/23868145

48) Shaikh, R., M. (2013). Socio-demographic Profile and Career Choice of Science Students: A study of Science Students of University of Pune, Pune, India. International $J$. on Integrating Technology in Education, 2(1), pp.1-8. https://doi.org/10.5121/ijite.2013.2101

49) Shumba, A. and Naong, M. (2012). Factors Influencing Students' Career Choice and Aspirations in South Africa. Journal of Social Sciences, 32(2), pp.169-178.

https://doi.org/10.1080/09718923.2012.118930 $\underline{96}$

50) Sibson, R. (2011). Career choice perceptions of undergraduate Event, Sport and Recreation Management students: An Australian case study. ECU Publications, pp.1-25.

http://ro.ecu.edu.au/cgi/viewcontent.cgi?article $=1212 \&$ context=ecuworks 2011 
51) Singh, A. and Masuku, M. (2014). Sampling techniques \& determination of sample size in applied statistics research: an overview. International J. of Economics, Commerce and Management, 2(11), p.11.

http://ijecm.co.uk/wp-content/uploads/2014/1 1/21131.pdf

52) Su, M., Chang, T., and Liao, C. (2016). Factors affecting the student career decision-making of junior high school students in central Taiwan area. International $J$. of Information and Education Technology, 6(11), pp.843850. https://doi.org/10.7763/ijiet.2016.v6.803

53) Zaidi, F. and Iqbal, S. (2012). Impact of career selection on job satisfaction in the ser-vice industry of Pakistan. African J. of Business Management, 6(9), pp.3385-3401. https://doi.org/10.5897/ajbm11.1708

Citation: Islam SA, Rahman GM, and Nibir MMAM. (2021). Perceived factors influencing career choice of the undergraduate students of public universities in Bangladesh, Can. J. Bus. Inf. Stud., 3(4), 70-79. https://doi.org/10.34104/cjbis.021.070079 @ @ 